But, I confess, I shall be very much disappointed if I am suffered to monopolize this department of the Magazine.

I am Sir,

Your most obedient servant,
Camden Town, 21st February, 1865.
P. GRAY.

\title{
ON THE TABLES OF DEFERRED ANNUITIES PUBLISHED BY THE NATIONAL DEBT OFFICE.
}

To the Editor of the Assurance Magazine.

Dear SIr, - In August, 1861, I drew the attention of your readers to the remarkable discrepancy which exists between the trne preminms, as dednced from the Government Tables at 3 per cent, and those charged by the Government on the purchase of those deferred annuities in which the premiums are "returnable," either on death or at the option of the purchaser at any time prior to the commencement of the annuity, pursnant to $16 \& 17$ Vict., eap. 45.

I am now induced to revert to the subject, for two especial reasons; the first being, that these premiums are, as $I$ am informed, computed at $3 \frac{1}{4}$ per cent., and not at 3 per cent. as assumed in my last letter, whereby the difference is greater than I had then stated; the second, because I did not then give the very simple method by which those preminms may be deduced from the materials furuished by the tables themselves-nor, in fact, as far as I am aware, has any method of dedueing premiums returnable at the option, as well as on the death, of a purchaser, been hitherto published in any work on life annuities.

The problem then is, to find the single premium for an ansuity during the remainder of a life $(x)$ after $n$ years, with the condition that the premium is "returnable," withont interest, on death or at the option of the purchaser at any time prior to the commencement of the annuity.

As the preminm $\left(\mathbf{P}_{x}\right)$ is repayable at any time during the term $(n)$, but without interest, it must be considered from two points of view; firstly, as a sum held on trust to be ready whenever called for; and, secondly, as a fund yielding an annual ineome which (not being repayable under any eircumstances) is to be applied year by year, during the term, in the purchase of an aunnity deferred for $n$ years; but at the expiration of the term of $n$ years, the condition as to the return of $P_{x}$ baving ceased, it must itself be applied to the purchase of an immediate annuity on the life at its then increased age of $(x+n)$ years.

Let $P_{x}=$ single preminm "returnable" for an annuity of $f 1$;

$i=$ interest on $\mathfrak{f l}$ for a year;

$p_{x_{n}}=$ the annual preminm payable at the end of the year for assuring to $x$ a deferred anmity of $£ l$ after $n$ years;

$a_{x+n}=$ annuity on a life aged $(x+n)$; then $P_{x} \cdot \frac{i}{p_{n}}=\begin{aligned} & \text { the amount of deferred annuity which can be assured by the } \\ & \text { conversion of the annual interest into an annual premium, }\end{aligned}$ and $P_{x} \cdot \frac{1}{a_{x \rightarrow n}}=$ the amount of annuity which can be obtained by sinking $P_{x}$ 
By addition,

$$
\begin{array}{r}
\mathrm{P}_{x}\left(\frac{i}{p_{x_{n}}}+\frac{1}{a_{x+n}}\right)=1, \\
\therefore \mathrm{P}_{x}=\frac{1}{\left(\frac{i}{p_{x_{n}}}+\frac{1}{a_{x+n}}\right)} .
\end{array}
$$

By an easy transformation to the columnar notation,

$$
\mathbf{P}_{x}=\frac{\mathrm{N}_{x+n}}{\left(\mathrm{~N}_{x}-\mathrm{N}_{x+n}\right) i+\mathrm{D}_{x+n}}
$$

As in the tables which we are now considering, $p_{x_{n}}\left(\right.$ being $\left.=\frac{\left.a_{x}\right\rceil_{n}}{a_{x}-a_{x}}\right)$ and $a_{x+n}$ are given, the following table was obtained with great facility, from which it will be seen that in the extreme case of an annaity to 31 after 50 years, the preminm charged by the Government is more than three and $a$ half times the correct amonnt.

Deferred Annuities of $\mathfrak{£} 30$, Males, Single Premiums, returnable without

\begin{tabular}{|c|c|c|c|c|c|}
\hline $\begin{array}{c}\text { Age } \\
\text { at } \\
\text { Entry. }\end{array}$ & Term. & $\begin{array}{l}\text { Govermment } \\
\text { Preminms. }\end{array}$ & $\begin{array}{l}\text { True Preminus, } \\
\text { computed on } \\
\text { Dita of Tables } \\
\text { at } 3 \frac{1}{4} \text { per Cent }\end{array}$ & $\begin{array}{c}\text { Difference } \\
\text { between } \\
\text { Government } \\
\text { Preminms and } \\
\text { true Premisms. }\end{array}$ & $\begin{array}{c}\text { Error } \\
\text { per Cent. }\end{array}$ \\
\hline $\begin{array}{l}21 \\
n \\
n \\
n\end{array}$ & 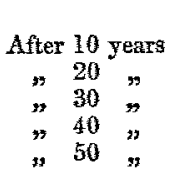 & $\begin{array}{c}£ \\
403-250 \\
261-750 \\
156 \cdot 875 \\
89695 \\
44.375\end{array}$ & $\begin{array}{c}f \\
394 \cdot 650 \\
242670 \\
133 \cdot 611 \\
62629 \\
21.864\end{array}$ & $\begin{array}{c}f \\
8.600 \\
19 \cdot 080 \\
23 \cdot 264 \\
27003 \\
22.511\end{array}$ & $\begin{array}{r}2179 \\
7 \cdot 865 \\
17411 \\
43 \cdot 120 \\
102959\end{array}$ \\
\hline $\begin{array}{l}31 \\
3 \\
\text { " } \\
\text { " }\end{array}$ & 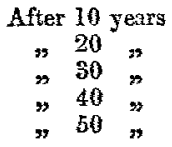 & $\begin{array}{l}360 \cdot 250 \\
216 \cdot \\
121 \cdot 375 \\
61 \cdot 125 \\
25 \cdot 250\end{array}$ & $\begin{array}{r}352 \cdot 900 \\
199 \cdot 467 \\
96 \cdot 429 \\
34 \cdot 881 \\
6923\end{array}$ & $\begin{array}{r}7 \cdot 450 \\
16533 \\
24 \cdot 946 \\
26 \cdot 244 \\
18 \cdot 327\end{array}$ & $\begin{array}{r}2 \times 112 \\
8 \cdot 289 \\
25 \cdot 869 \\
75 \cdot 239 \\
264 \cdot 726\end{array}$ \\
\hline $\begin{array}{l}41 \\
\Rightarrow \\
" \\
"\end{array}$ & $\begin{array}{c}\text { After } 10 \text { years } \\
=20 \\
=30 \\
=40\end{array}$ & $\begin{array}{r}297 \cdot 375 \\
167 \cdot 125 \\
84 \cdot 125 \\
34 \cdot 750\end{array}$ & $\begin{array}{r}290 \cdot 646 \\
146 \cdot 631 \\
560133 \\
11.554\end{array}$ & $\begin{array}{r}6729 \\
20 \cdot 491 \\
28 \cdot 112 \\
23 \cdot 196\end{array}$ & $\begin{array}{r}2 \cdot 315 \\
13 \cdot 974 \\
50 \cdot 188 \\
200 \cdot 761\end{array}$ \\
\hline $\begin{array}{l}51 \\
\Rightarrow \\
\Rightarrow\end{array}$ & $\begin{array}{c}\text { After } 10 \text { years } \\
=20 \% \\
\Rightarrow \quad 30 \Rightarrow\end{array}$ & $\begin{array}{l}230 \\
115 \cdot 875 \\
47 \cdot 875\end{array}$ & $\begin{array}{r}220 \cdot 467 \\
91 \cdot 128 \\
20 \cdot 550\end{array}$ & $\begin{array}{r}9 \times 333 \\
24747 \\
27 \cdot 325\end{array}$ & $\begin{array}{r}4.325 \\
27156 \\
132.968\end{array}$ \\
\hline
\end{tabular}
Interest at any time prior to commencement of Annuity, pursuant to $16 \$ 17$ Vict., cap. 45.

The results given in the foregoing examples are so startling, that I have been indaced to prepare a second table, showing what proportion of the whole annuity which is to be entered apon at the end of the term is assured by the yearly application of the interest on the single premium, and what proportion is yielded by sinking the single preminm at the end of the term. 


\begin{tabular}{|c|c|c|c|c|c|}
\hline $\begin{array}{c}\text { Age } \\
\text { at } \\
\text { Entry. }\end{array}$ & Term. & $\begin{array}{l}\text { Annual Income } \\
\text { from Interest } \\
\text { on Single } \\
\text { Premium. }\end{array}$ & $\begin{array}{l}\text { Deferred } \\
\text { Annuity which } \\
\text { Annual Interest } \\
\text { will assure. }\end{array}$ & $\begin{array}{c}\text { Annuity which } \\
\text { Single Preminm } \\
\text { will purchase at } \\
\text { the end of the } \\
\text { Term. }\end{array}$ & $\begin{array}{c}\text { Sum of last } \\
\text { two Columns, } \\
\text { being } \\
\text { Total Benefit } \\
\text { secured. }\end{array}$ \\
\hline$(x)$. & n. & $P_{x}+i$ & $\mathrm{P}_{x \cdot \frac{i}{p_{x}}}$ & $P_{x} \cdot \frac{1}{a_{x+n}}$ & \\
\hline $\begin{array}{l}21 \\
" \\
" \\
"\end{array}$ & $\begin{array}{l}10 \text { years } \\
20 " \# \\
30 " \\
40 " \\
50 "\end{array}$ & $\begin{array}{r}12 \cdot 826 \\
7 \cdot 886 \\
4 \cdot 342 \\
2 \cdot 035 \\
710\end{array}$ & $\begin{array}{r}8 \cdot 676 \\
15-327 \\
20 \cdot 209 \\
24 \cdot 073 \\
27 \cdot 012\end{array}$ & $\begin{array}{r}21 \cdot 324 \\
14 \cdot 673 \\
9 \cdot 791 \\
5 \cdot 927 \\
2 \cdot 988\end{array}$ & $\begin{array}{c}£ 30 \\
" \\
" \\
"\end{array}$ \\
\hline $\begin{array}{l}31 \\
" \\
" \\
"\end{array}$ & $\begin{array}{l}10 \text { years } \\
20 " \\
30 " \\
40 " \\
50 "\end{array}$ & $\begin{array}{r}11 \cdot 466 \\
6 \cdot 482 \\
3 \cdot 134 \\
1 \cdot 133 \\
\cdot 225\end{array}$ & $\begin{array}{r}8 \cdot 666 \\
15 \cdot 385 \\
20 \cdot 867 \\
25 \cdot 233 \\
28 \cdot 337\end{array}$ & $\begin{array}{r}21 \cdot 334 \\
14 \cdot 618 \\
9 \cdot 133 \\
4 \cdot 767 \\
1 \cdot 663\end{array}$ & $\begin{array}{r} \pm 30 \\
" \\
" \\
"\end{array}$ \\
\hline $\begin{array}{l}41 \\
" \\
" \\
\Rightarrow\end{array}$ & $\begin{array}{l}10 \text { years } \\
20 " \\
30 " \\
40 "\end{array}$ & $\begin{array}{r}9 \cdot 446 \\
4.765 \\
1 \cdot 820 \\
+375\end{array}$ & $\begin{array}{r}8 \cdot 701 \\
16 \cdot 080 \\
22 \cdot 344 \\
27 \cdot 224\end{array}$ & $\begin{array}{r}21 \cdot 299 \\
13 \cdot 920 \\
7 \cdot 656 \\
2 \cdot 776\end{array}$ & $\begin{array}{r} \pm 30 \\
" \\
" \\
"\end{array}$ \\
\hline $\begin{array}{l}51 \\
\Rightarrow \\
\Rightarrow\end{array}$ & $\begin{array}{l}10 \text { yearz } \\
20 \% \\
30 \%\end{array}$ & $\begin{array}{r}7 \cdot 165 \\
2 \cdot 961 \\
\cdot 667\end{array}$ & $\begin{array}{r}9 \cdot 119 \\
17 \cdot 545 \\
25 \cdot 063\end{array}$ & $\begin{array}{r}20 \cdot 881 \\
12.455 \\
4937\end{array}$ & $\begin{array}{r}£ 30 \\
" \\
"\end{array}$ \\
\hline
\end{tabular}

If not trespassing too much on your valuable space, I should like to give one practical example in illustration of the previous observations.

Let us then suppose the case of a man aged 25 , possessed of a capital of $\$ 47.18 \mathrm{~s}$. $4 \mathrm{l}$., which yields him an anmul income (at $3 \frac{1}{4}$ per cent.) of £1. 11s. $2 d$; either, or both, of which he is desirous of devoting to a provision for old age.

On turning to Table No, 2 (money returnable), he will find that his capital is exactly sufficient to proxide an annuity of $\mathfrak{f 2 0}$ after 41 years, with the option of having his money retnrned at any time prior to the commencement of the annaity.

Bat on turning to Table No. 3 (money not returnable), he will see that, by devoting the yearly income of $\mathrm{fl} .11 \mathrm{~s} .2 d$, be can assure an annuity of £24. 18s. $8 d$, instead of $f 20$, and not part with his expital at all; and he will further discover, on looking to the table of immediate annuities, that if he wish to part with his money at the end of the term he can purchase a further annuity of $£ 5.7 s .9 d$, making together $f 30.6 s .5 d$, , instead of $\$ 20$-a result which will be fonnd to be fully confirmed by my previons deductions.

I bave now practically shown that a person can secure a deferred aunuity under Table No. 3, greater than he can assare under Table No. 2 by 51.6 per cent., on precisely the same security and at precisely the same expenditure in both instances, with the additional advantage that in the former case he can at the end of the term exercise an option against the Government, should his then state of health render such a course desirable; but even this does not fully describe all the disadvantages which he snffers under Table No. 2, as circumstances, other than his state of health, may render it necessary for him to divert his capital into some other channel at the end of the term; should this be so, he will nnder Table No. 2 have secured 
nothing in the shape of an annuity, whilst ander Table No. 3 he will receive £24. 18s. 8d. per annum for the remainder of his life. In this illastration I have disregarded the provision of the Act, that no person can assure an annuity of more than $\mathfrak{E} 30$, and also any rule which may exist as to insuring fractions of a pond, as these can have no bearing on the question before us; but it may, perhaps, be as well to point out that, as in the Government tables, the preminms for deferred annuities are, of course, payable at the beginning, whilst in the formula which $I$ bave given they are payable at the end of the year, the assurance under Table No. 3 must be made at the age of $x+1$ for $n-1$ years.

In conclusion, allow me to draw your attention to the table for deferred annuities (money not retarnable), which has this week been laid before Parliament. In it are given tables of immediate annuities and tables of deferred annuities; with these materials, the valnes of annuities for terms of years are immediately obtained, with the following results:-

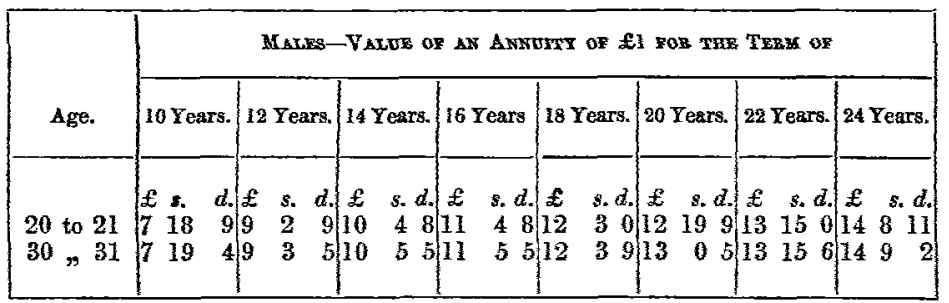

in all of whieh cases it will be seen that the value of a life at 31 is greater than that of a life at 21 ; and similarly it may be shown that the value of an annuity for 10 years is precisely the same at the ages of 21 and 39 .

I hope, on a future occasion, to be allowed to prove that the annnal premiums payable under the "money returnable" scale are open to the same objections, although not to the same degree, as those which I have urged against the single premiums under a like condition.

I am, dear Sir,

Yours truly,
London, 25th February, 1865.
J. W. STEPHENBON.

\section{MR. SPRAGUE'S LETTER IN THE LAST NUMBER OF THE JOURNAL.}

To the Editor of the Assurance Magazine.

Sik,-It was my intention to have asked yon to be good enough to insert a reply, which I have written at some length, to the letter of Mr. Sprague which appeared in the last Number of the Magazine. But some of my friends, on whose judgment I piace great reliance, who have seen the manascript, arge me to withdraw it, on the ground that the affairs of particular Societies ought not, under any circumstances, to be discussed in the Journal of the Institute. For this reason, and for this reason only, I abstain from entering into further controversy on the subject.

I have the honour to be,

$$
\begin{aligned}
& \text { Sir, } \\
& \text { Your obedient servant, }
\end{aligned}
$$

10 th March, 1865.

ARTHUR H. BAILEY. 